\title{
Point Mutation Causing a Single Amino Acid Substitution in the Hormone Binding Domain of the Glucocorticoid Receptor in Familial Glucocorticoid Resistance
}

\author{
David M. Hurley, ${ }^{*}$ Domenico Accili," Constantine A. Stratakis, ${ }^{\star}$ Michael Karl," Nikos Vamvakopoulos," Eva Rorer," \\ Kostas Constantine, " Simeon I. Taylor," and George P. Chrousos* \\ *Developmental Endocrinology Branch, National Institute of Child Health and Human Development; and ${ }^{\ddagger}$ Diabetes Branch, \\ National Institute of Diabetes, Digestive and Kidney Disease, National Institutes of Health, Bethesda, Maryland 20892
}

\begin{abstract}
Familial glucocorticoid resistance is a hypertensive, hyperandrogenic disorder characterized by increased serum cortisol concentrations in the absence of stigmata of Cushing's syndrome. Our previous studies of the first reported kindred showed a two- to threefold reduction in glucocorticoid receptorligand binding affinity in the propositus, and a lesser reduction in affinity in his mildly affected son and nephew. Glucocorticoid receptor cDNA from these three patients was amplified by polymerase chain reaction and sequenced. The cDNA nucleotide sequence was normal, except for nucleotide 2054 , which substituted valine for aspartic acid at amino acid residue 641 . The propositus was homozygous while the other relatives were heterozygous for the mutation. COS-7 monkey kidney cells were cotransfected with expression vectors for either wild type or Val 641-mutant receptors, together with the reporter plasmid pMMTV-CAT. Dexamethasone increased chloramphenicol acetyltransferase activity in cells expressing wild type receptor, but had no effect in cells expressing Val 641-mutant receptors, despite similar receptor concentrations, as indicated by Western blotting. The binding affinity for dexamethasone of the Val 641-mutant receptor was threefold lower than that of the wild type receptor. These results suggest that glucocorticoid resistance in this family is due to a point mutation in the steroidbinding domain of the glucocorticoid receptor. (J. Clin. Invest. 1991. 87:680-686.) Key words: polymerase chain reaction sequencing $\bullet$ hypercortisolemia
\end{abstract}

\section{Introduction}

The profound effects of glucocorticoid hormones on gene transcription in virtually all tissues are mediated by the glucocorticoid receptor (GR), ${ }^{1}$ the prototypic member of a family of ligand-activated transcription factors homologous to the v-erb $A$ oncogene (1). The primary structure of the human GR (hGR)

Part of this work was presented at the June 1990 Annual Meeting of the American Endocrine Society, Atlanta, Georgia.

Address correspondence and reprint requests to Dr. George P. Chrousos, National Institutes of Health, Building 10, Room 10 N 262, Bethesda, MD 20892.

Received for publication 26 April 1990 and in revised form $10 \mathrm{Au}$ gust 1990.

1. Abbreviations used in this paper: $\mathrm{A}$, adenosine; $\mathrm{c}$, complimentary; FGR, familial glucocorticoid resistance; GRE, glucocorticoid response elements; hGR, human glucocorticoid receptor; PCR, polymerase chain reaction; $T$, thymidine.

The Journal of Clinical Investigation, Inc.

Volume 87, February 1991, 680-686 has been deduced from complementary (c) DNA cloning (2), and the hGR gene has been localized on chromosome $5(2,3)$. It has been suspected that a mutation in the hGR gene is responsible for the syndrome of familial glucocorticoid resistance (FGR) (4-7). In this condition, serum cortisol concentrations and cortisol production rate are greatly increased, without the characteristic clinical and biochemical stigmata of glucocorticoid excess. Plasma ACTH concentrations are also elevated, despite cortisol hypersecretion, and the hypothalamic-pituitary-adrenal axis is resistant to suppression by exogenous glucocorticoids. These changes reflect generalized tissue resistance to cortisol, which appears to be compensated for by high ACTH and cortisol concentrations $(4,5)$. The high ACTH levels, however, also participate in the pathophysiology of the syndrome by stimulating adrenal secretion of salt-retaining hormones and androgens. These, respectively, interact with the mineralocorticoid receptor and androgen receptor, thereby causing hypertension and hypokalemic alkalosis in both sexes and/or hyperandrogenism in women $(5,8)$. Male precocious puberty has also been described (9).

We have conducted extensive studies of the large kindred, in which FGR was first described, to identify the molecular basis of the syndrome $(5,7,10,11)$. The propositus had no features of glucocorticoid excess despite a sevenfold elevation of nonprotein bound cortisol in serum and a 30-40 fold increase in urinary free cortisol excretion. The dose of dexamethasone needed to suppress serum cortisol levels by $50 \%$ in this patient was seven times greater than in normal subjects (5). Less severe but unequivocal cortisol excess and dexamethasone resistance were found in one son and one nephew. Borderline cortisol excess was detected in 6 of 27 additional relatives from three generations (7), consistent with an autosomal codominant mode of inheritance in which heterozygotes are mildly affected.

The concentrations of GR in intact mononuclear leukocytes from the propositus and his mildly affected son were normal, but the affinity of ligand binding was two- to threefold lower than in cells from normal subjects $(5,11)$. Borderline decreases in affinity were also seen in his son $(5,11)$. To facilitate further studies, lymphoblast cell lines were established by Epstein-Barr virus transformation of peripheral blood lymphocytes obtained from the propositus and from his mildly affected son and nephew (12). GR in the lymphoblasts of these patients had similar binding properties to GR in their untransformed cells. The hormone-receptor complex of the propositus migrated with the expected molecular size, but exhibited increased thermolability and reduced binding to DNA cellulose after thermal activation (12). Northern blot analysis demonstrated specific GR mRNA of the expected size (7). It was concluded from these studies that the most likely molecular defect was a mutation of the GR gene located in the region that encodes the hormone binding domain of the receptor. In this 
study, we used the polymerase chain reaction (PCR) (13) to amplify the patients' GR cDNA and identified a mutation substituting valine for $\mathrm{Asp}^{641}$ in the hormone binding domain of the receptor. This mutation causes glucocorticoid resistance with codominant inheritance.

\section{Methods}

Cell lines. EBV-transformed lymphoblast lines previously established from the propositus and his son and nephew $(12,14)$ were grown in RPMI 1640 medium, supplemented with $10 \%$ fetal bovine serum and 2 mM glutamine. COS-7 monkey kidney cells were grown as monolayers in Dulbecco's modified Eagle's medium (Biofluids Inc., Rockville, MD), supplemented with $10 \%$ (vol/vol) charcoal-treated fetal bovine serum (Biofluids Inc.), $100 \mathrm{U} / \mathrm{ml}$ penicillin and streptomycin and $\mathrm{L}-$ glutamine at $37^{\circ} \mathrm{C}$ in a $5 \% \mathrm{CO}_{2}$ atmosphere.

Isolation of RNA, reverse transcription, PCR amplification. Total RNA was isolated from the cultured lymphoblasts by the acid-guanidinium-thiocyanate-phenol-chloroform method (15). mRNA was obtained by oligo(dT) chromatography (New England Biolabs, Beverly, MA). Single-stranded cDNA was synthesized from total RNA or mRNA by a specifically primed reverse transcription reaction using Avian Myeloblastosis Virus (AMV)-reverse transcriptase (Boehringer Mannheim Biochemicals, Indianapolis, IN). $1 \mu \mathrm{g}$ of mRNA or $10 \mu \mathrm{g}$ of total RNA were reverse transcribed in the presence of $2.5 \mathrm{mM}$ of each dNTP, 5 pmol of a specific antisense primer (No. 2 or 6; Table I), reverse transcriptase buffer, and $27 \mathrm{U}$ of the enzyme at $42^{\circ} \mathrm{C}$ for $1 \mathrm{~h}$. An aliquot of the reaction mixture was heated to $95^{\circ} \mathrm{C}$ for $5 \mathrm{~min}$ and then added to a PCR mixture containing $2.5 \mathrm{U}$ of Taq polymerase (Perkin Elmer-Cetus Corp., Emeryville, CA) and 50 pmol of sense and antisense primers. Primers 3 and 13 were used to amplify hGR cDNA (1105-2500), encoding both DNA- and ligand-binding domains; primers 6 and 10 were used to amplify hGR cDNA (113-1291) (Table I, Fig. 1). 30 cycles of PCR were carried out, using the Perkin Elmer-Cetus thermal cycler. Each cycle consisted of incubations of $40 \mathrm{~s}$ at $95^{\circ} \mathrm{C}$ for denaturation, $90 \mathrm{~s}$ at $55^{\circ} \mathrm{C}$ for annealing and $2 \min 30 \mathrm{~s}$ at $72^{\circ} \mathrm{C}$ for primer extension. The initial denaturation period was $5 \mathrm{~min}$, and the initial extension time was $30-45 \mathrm{~min}$. The final extension time was $10 \mathrm{~min}$.

$P C R$ primers, asymmetric $P C R, D N A$ sequencing. Oligonucleotide primers were synthesized by phosphoramidite chemistry, using a DuPont Co. Coder 300 (Wilmington, DE). Nucleotide sequences were based on the normal hGR cDNA sequence (2) (Table I). The primers were used in PCRs to synthesize double-stranded cDNA in order to obtain overlapping segments for determination of the nucleotide sequence. The location of the PCR primers and the strategy for sequencing the entire 2.3-kb coding region of the hGR are shown in Fig. 1. Direct sequencing of the amplified cDNA was performed according to a modification of the method of Kadowaki et al. (16). The amplified double-stranded hGR cDNA segments were further amplified to obtain single-stranded CDNA in a second PCR reaction with one of the primers in excess. After Centricon-100 ultrafiltration (Amicon Corp., Danvers, MA) to remove excess primers and unincorporated nucleotides, the products of the asymetric PCRs were sequenced by the Sanger dideoxynucleotide chain termination method (17), using modified T7. DNA polymerase (Sequenase; United States Biochemical Corp., Cleveland, $\mathrm{OH}$ ) and the limiting oligonucleotide or an internal sequencespecific primer, labeled with $\left[\gamma-32\right.$ p]ATP. In later experiments $\left[\alpha^{35} S\right]-$ dATP was used. Products of the sequencing reaction were electrophoresed at $60 \mathrm{~W}$ on $6 \%$ polyacrylamide $/ 8 \mathrm{M}$ urea gels which, after drying, were placed in contact with Kodak X-Omat AR film at $-70^{\circ} \mathrm{C}$ overnight.

Restriction endonuclease digestion of PCR-amplified cDNAs. The restriction endonuclease enzyme Mae-II (Boehringer Mannheim Biochemicals) was used to digest the 1.4-kb PCR product encoding both the ligand and DNA binding domains of the receptor CDNA from the patients (Fig. 1). The ends of the generated fragments were then labeled using $\left[\alpha-{ }^{32} \mathrm{P}\right] \mathrm{dCTP}$ and $2 \mathrm{U}$ of Klenow enzyme (labeling grade; Boehringer Mannheim Biochemicals). The resulting segments were resolved in 5\% polyacrylamide gel, which was dried and exposed for $1 \mathrm{~h}$ to Kodak X-Omat film.

Table I. Sequences of Synthetic Oligonucleotides

\begin{tabular}{|c|c|c|}
\hline Oligonucleotide & hGR cDNA-site & $\begin{array}{c}\text { Sense }(s) \text { or } \\
\text { antisense (as) }\end{array}$ \\
\hline 1. 5'-TGCTATCCTAACTATACAGG-3' & $2874-2893$ & (as) \\
\hline 2. 5'-TATAAACCACATGTAGTGCG-3' & $2599-2618$ & (as) \\
\hline 3. 5'-AACCTCTACAGGACAAACTG-3' & $2531-2550$ & (as) \\
\hline 4. 5'-CCACTTCATGCATAGAATCC-3' & $2298-2317$ & (as) \\
\hline 5. 5'-GTGGTAACGTTGCAGGAACTATTG-3' & $1688-1707$ & (as) \\
\hline 6. 5'-TTCCGTCGACTTCGACCAGGGAAGTTCAGA-3' & $1272-1291$ & (as) \\
\hline 7. 5'-TTCCGTCGACTTGCCTGACAGTAAACTGTG-3' & $1026-1045$ & (as) \\
\hline 8. $5^{\prime}$-CAGAAGAAAACTCCAAATCC- $3^{\prime}$ & $717-726$ & (as) \\
\hline 9. 5'-ACGTGGTACCCTGCGTTCACAAGCTAAGTT-3' & $39-58$ & (s) \\
\hline 10. 5'-ACGTGGTACCGCCAGAGTTGATATTCACTG-3' & $113-132$ & (s) \\
\hline 11. 5'-AGCAGTTTCACTCTCAATGG-3' & $370-389$ & (s) \\
\hline 12. 5'-ACGTGGTACCCCAGTAATGTAACACTGCCC-3' & $935-954$ & (s) \\
\hline 13. 5'-ACGTGGTACCAGTACCTCTGGAGGACAGAT-3' & $1105-1124$ & (s) \\
\hline 14. 5 '-GACCAGATGTAAGCTCTCCT- $3^{\prime}$ & $1328-1347$ & (s) \\
\hline 15. 5'-TGGAGATCATATAGACAATCA-3' & $1960-1980$ & (s) \\
\hline 16. 5'-CAGGTATCTTATGAAGAGTATCTC-3' & $2101-2124$ & (s) \\
\hline 17. 5'-TGAGCAGAGAATGACTCTACC-3' & 2021-2042 & (s) \\
\hline 18. 5'-GTAAGGTTTTCATACAGAGAT-3' & $2120-2141$ & (as) \\
\hline
\end{tabular}

Oligonucleotides No. 1-16 were used in PCR amplifications of overlapping segments of the hGR cDNA and in subsequent sequencing; No. 17 and 18 were used for the amplification of the genomic DNA from normal individuals (segment $C$, Fig. 1). Primers No. 1-8 and 18 are antisense, and primers $9-17$, sense. Underlined sequences of oligonucleotides are restriction endonuclease recognition sites to facilitate further cloning. 


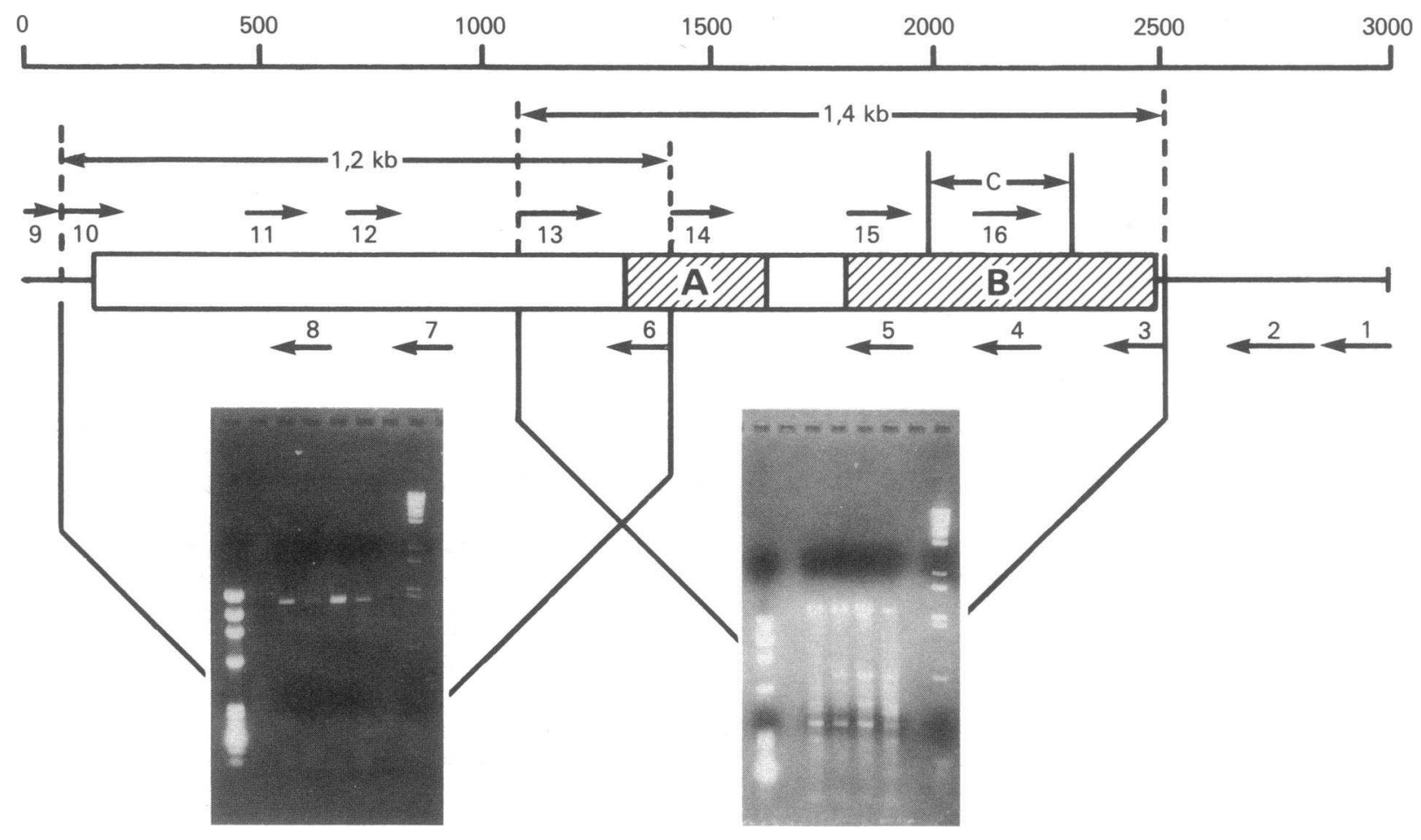

Figure 1. The coding region of the hGR cDNA (1.2). $A$ and $B$ encode the DNA and hormone binding domains of the hGR. The locations of oligonucleotide primers used in PCR and sequencing reactions are shown by the numbered arrows. The upper scale denotes nucleotide position. The ethidium bromide-stained 1\% agarose gels show that PCR amplified hGR cDNA of the three patients and normal hGR cDNA using primers 6 and 10 (left), and primers 3 and 13 (right), yielded the expected 1.2-kb and 1.4-kb fragments, respectively, excluding major deletions, insertions, or other rearrangements. Region $C$ represents the segment of genomic DNA which was amplified from normal subjects.

Hybridization with synthetic oligonucleotides. Two synthetic oligonucleotides (18mers) were made, one bearing the identified base substitution (5'-CATGTACGTCCAATGTAA-3'; the T in place of the normal $A$ at position 2054 is underlined) and the other consisting of the normal sequence $3^{\prime}$ to the base substitution site $\left(5^{\prime}\right.$ CCAATGTAAACACATGCT-3'; nucleotides in common with the oligonucleotide bearing the base substitution are underlined). Both probes were labeled with $\left[\gamma_{-}{ }^{32} \mathrm{P}\right] \mathrm{ATP}$ using T4-polynucleotide kinase (Boehringer Mannheim Biochemicals) at $37^{\circ} \mathrm{C}$ for $30 \mathrm{~min}$. Unincorporated ATP was removed by gel filtration on a Sephadex G-25 column. PCR-amplified hGR cDNA encoding the hormone binding domain (including the 2054 site) from the propositus cDNA, normal hGR cDNA, kindly donated by Dr. Stanley Hollenberg (Salk Institute, La Jolla CA), and genomic DNA from 24 normal subjects was size fractionated on a $1.2 \%$ NuSieve Agarose gel and transferred to Genescreen Plus hybridization membrane (DuPont Co.) (18). PCR primers 17 and 18 were used to amplify genomic DNAs (Table I). Blots were hybridized with each probe at $37^{\circ} \mathrm{C}$ overnight in a solution containing $5 \times$ SSPE, $5 \times$ Denhardt solution and $0.5 \%$ SDS, washed twice at room temperature for $5 \mathrm{~min}$ in a solution containing $2 \times \mathrm{SSPE}$ and $0.5 \% \mathrm{SDS}$, and then at $53^{\circ} \mathrm{C}$ (mutant oligonucleotide) or $55^{\circ} \mathrm{C}$ (normal oligonucleotide) in a solution containing $5 \times$ SSPE and $0.5 \%$ SDS and autoradiographed, as previously described (19).

Site-directed mutagenesis and cloning of the Val 641-mutant glucocorticoid receptor. The technique of site-directed mutagenesis by overlap extension PCR (20) was employed to replace the adenosine (A) residue at position 2054 of the normal hGR cDNA with a thymidine (T) residue, using the pRShGR $\alpha$ expression vector (21), kindly provided by Dr. Stanley Hollenberg, as template. Two pairs of oligonucleotide primers (Table II) were used in PCR's to amplify overlapping hGR cDNA fragments that incorporated the base substitution. An aliquot of each of the initial reactions was then added to a third PCR mixture containing primers No. 1 and 4 (Table II), in order to amplify the hGR cDNA region (1586-2404).

The product of the third PCR was digested with Eco RI. The Cla I-Xho I fragment (including hGR cDNA nucleotides 1526-2463) of the pRShGR $\alpha$ expression vector was inserted into the multiple cloning site of Bluescript plasmid (Stratagene, La Jolla, CA). After digestion of the recombinant plasmid with Eco RI, the digested PCR fragment was ligated into the plasmid to replace the wild-type sequence. Subsequently, the recombinant Cla I-Xho I fragment of the hGR cDNA was ligated back into the pRShGR $\alpha$. Sequencing of the full length Cla IXho I insert within the hGR cDNA of the recombinant plasmid pRShGR $\alpha$ confirmed the presence of the mutation without any other base changes. The recombinant plasmid was designated RShGRVal 641.

Table II. Primers Used for the Site-directed Mutagenesis PCR

\begin{tabular}{lcc}
\hline \multicolumn{1}{c}{ Sequence } & cDNA site & $\begin{array}{c}\text { Sense }(s) \text { or } \\
\text { antisense }(a s)\end{array}$ \\
\hline 1. 5'-GAATGAACCTGGAAGCTCGA-3' & $\underline{1586-1605}$ & (s) \\
2. 5'-CATTGGÁCGTACATGCAGGG-3' & $\underline{2041-2060}$ & (as) \\
3. 5'-CGTCCAATGTAAACACATGC-3' & $\underline{2052-2071}$ & (s) \\
4. 5'-TGATGATTTCAGCTAACATCT-3' & $\underline{2384-2404}$ & (as)
\end{tabular}

Primers No. 1 and 2 were used for one PCR amplification and primers 3 and 4 for the other, resulting in products that overlap at the underlined sequences. The starred base is the inserted base change. Both products were used as template in a third PCR, with the "external" primers 1 and 4. 
Cotransfection assay. COS-7 cells were plated on $60-\mathrm{mm}$ tissue culture dishes $\left(5 \times 10^{5} \mathrm{cells} / \mathrm{plate}\right)$ and grown overnight to near confluence (21). After washing with $5 \mathrm{ml}$ calcium- and magnesium-free PBS, culture dishes were incubated for $5 \mathrm{~h}$ with $3 \mathrm{ml} /$ plate Optimem I (Gibco Laboratories, Grand Island, NY) containing a mixture of $50 \mu \mathrm{g}$ lipofectin (22) (BRL, Gaithersburg, MD), $1 \mu \mathrm{g}$ of the expression vector encoding either the wild type hGR, Val 641-mutant hGR or the truncated nonhormone binding hGR $\beta$ (21) and $5 \mu \mathrm{g}$ of the reporter plasmid, MMTV-CAT (21). For mock transfections, $1 \mu \mathrm{g}$ of the plasmid hsp 90 $\alpha$, provided by Dr. Hickey and Dr. Weber (University of South Florida, Tampa, FL) and $5 \mu \mathrm{g}$ reporter plasmid were used. Transfections were stopped by adding $3 \mathrm{ml}$ of growth medium supplemented with $20 \%$ charcoal-treated fetal bovine serum (vol/vol). After $15 \mathrm{~h}$, normal growth medium containing dexamethasone at concentrations of 0 to $10^{-6} \mathrm{M}$ was added. $2 \mathrm{~d}$ after transfection, cells were washed twice with PBS and harvested by scraping. Cell extracts were made by three cycles of freezing and thawing. Protein concentrations of the extracts were determined using a Coomasie Protein Assay Reagent (Pierce Chemical Co., Rockford, IL). CAT activity was assayed by monitoring the transfer of acetyl groups from acetyl-CoA to $\left[{ }^{14} \mathrm{C}\right]$ chloramphenicol, using thin layer chromatography (23). The results were quantified with a Betascope 603 Blot Analyzer (Betagen, Waltham, MA). Activities were determined as the percentage of chloramphenicol acetylated per hour per $10 \mu \mathrm{g}$ total protein.

Western blots. COS-7 cells transfected with either the wild type or the Val 641-mutant GR expression plasmids were harvested, and the cell pellets were stored at $-70^{\circ} \mathrm{C}$ for $2-3 \mathrm{~d}$. After thawing, cells were solubilized in $1 \%$ Triton X-100, and the receptors were immunoprecipitated, using a mouse monoclonal anti-glucocorticoid receptor antibody (generously provided by Dr. A. C. Wikstrom and Dr. J. A. Gustafsson). The immune complexes were precipitated with Protein $A$ (Calbiochem-Behring Corp., La Jolla, CA) and washed three times in $0.1 \%$ Triton $\mathrm{X}-100,50 \mathrm{mM}$ Hepes, pH 7.6, $150 \mathrm{mM} \mathrm{NaCl}, 0.1 \mathrm{mM}$ PMSF, and $10 \mu \mathrm{g} / \mathrm{ml}$ pepstetin. The final pellet was prepared for SDS/ polyacrylamide gel electrophoresis, as previously described (19). Proteins were transferred to nitrocellulose (Schleicher \& Schuell, Inc., Keene, $\mathrm{NH}$ ) by electroblotting for $1 \mathrm{~h}$ at $90 \mathrm{mV}$ in a $20 \%$ methanol/25 $\mathrm{mM}$ Tris/ $192 \mathrm{mM}$ glycine/0.01\% SDS buffer. The blot was soaked at $42^{\circ} \mathrm{C}$ in a solution of $5 \% \mathrm{BSA}, 0.5 \mathrm{M} \mathrm{NaCl}, 20 \mathrm{mM}$ Tris- $\mathrm{HCl}, \mathrm{pH} 7.4$, for 4-6 h, then incubated at room temperature for $3 \mathrm{~h}$ in a solution containing $0.5 \%$ BSA, $0.5 \mathrm{M} \mathrm{NaCl}, 20 \mathrm{mM}$ Tris- $\mathrm{HCl}, \mathrm{pH} 7.4,0.05 \%$ Tween 20, and a 1:100 dilution of anti-hGR-antibody. The blot was extensively washed in the same solution without antibody for $90 \mathrm{~min}$, incubated for $2 \mathrm{~h}$ in the same solution containing $200,000 \mathrm{cpm} / \mathrm{ml}$ of ${ }^{125}$ I-goat anti-mouse antibody, and then washed extensively in the same solution. Proteins were visualized in Kodak X-Omat films by autoradiography of the dried blots for 24-48 h.

Binding assays. COS-7 cells transfected with either wild type or Val 641-mutant GR plasmids were suspended in TEDGM buffer $(10 \mathrm{mM}$ Tris-HCI, $1.5 \mathrm{mM}$ EDTA, 3\% Glycerol, $0.5 \mathrm{nM}$ dithiothreitol, and 20 nM sodium molybdate, $\mathrm{pH} 7.4$ ) and homogenized with a teflon-coated mortar and pestle at $4^{\circ} \mathrm{C}$. Cytosol was obtained by ultracentrifugation at $105,000 \mathrm{~g}$ at $4^{\circ} \mathrm{C}$ for $1 \mathrm{~h}$. Aliquots of cytosol were incubated with $\left[{ }^{3} \mathrm{H}\right]$ dexamethasone at four concentrations $(1-20 \mathrm{nM})$ in the absence and presence of 50 -fold excess of unlabeled hormone, at $4^{\circ} \mathrm{C}$ for $18 \mathrm{~h}$ to determine total and nonspecific binding, respectively. The receptorbound ${ }^{3} \mathrm{H}$-steroid was separated from the unbound steroid by addition of a $0.5 \%$ charcoal solution, coated with dextran $(1.0 \%)$ followed by centrifugation at $3,000 \mathrm{rpm}$ at $4^{\circ} \mathrm{C}$ for $15 \mathrm{~min}$. An aliquot was counted in a $\beta$-counter, and specific binding was calculated by subtracting nonspecific from total binding. The cytosol protein concentrations were determined using a Coomassie Protein Assay Reagent. The data was then analyzed by the method of Scatchard. Binding capacities were expressed as $\mathrm{fmol} / \mathrm{mg}$ protein and $K_{\mathrm{d}}$ in $\mathrm{mM}(5)$.

\section{Results}

The 2.3-kb coding region of the GR cDNA, obtained by specifcally primed reverse transcription of RNA from the EBV- transformed lymphoblast lines established from the three patients, was amplified in two overlapping segments by the PCR. Both amplified segments were of the predicted size $(1.2 \mathrm{~kb}$ and $1.4 \mathrm{~kb}$, respectively, Fig. 1). We determined the nucleotide sequence of the coding region of GR cDNA according to a strategy summarized in Fig. 1 and Table I. Overlapping segments of double-stranded cDNA were amplified by PCR, and subsequently reamplified in asymmetric PCRs to yield singlestranded cDNA that was used as template for sequencing reactions.

The 1.4-kb region encompassed by primers 3 and 13 , encoding both the ligand and DNA binding domains of the hGR (Fig. 1), was initially selected for amplification and sequencing. PCR amplification and subsequent sequencing of this region in both orientations was performed multiple times, with different batches of cDNA prepared from total RNA and mRNA from all three patients. There was complete concordance with the published normal nucleotide sequence, except at nucleotide 2054 , where a $\mathrm{T}$ residue was present in place of the normal $\mathrm{A}$. This base change results in a nonconservative amino acid substitution at position 641 of the hGR protein. Thus, the aspartic acid codon (GAC) was changed to a valine codon (GTC) (Fig. 2 ). In the propositus, only $T$ was identified at nucleotide 2054 , suggesting that this severely affected patient was homozygous for the Val 641 mutation. The nucleotide sequences of amplified GR cDNA from the mildly affected son and nephew contained both $A$ and $T$ residues at position 2054, suggesting heterozygosity (Fig. 2). To reveal other possible changes in the remaining sequence of the hGR cDNA of the three patients, the rest of the coding region of the receptor cDNA was sequenced, following a similar strategy (Fig. 1). No other alteration was found in the full length sequence of the $2.3-\mathrm{kb}$ coding region of the hGR cDNA in any of the three patients.

Substitution of $A$ for $T$ at position 2054 created a new recognition site for the restriction endonuclease Mae II. Digestion of PCR-amplified normal hGR cDNA with this enzyme yielded the expected 0.6- and 0.85-kb fragments. Digestion of the pro-
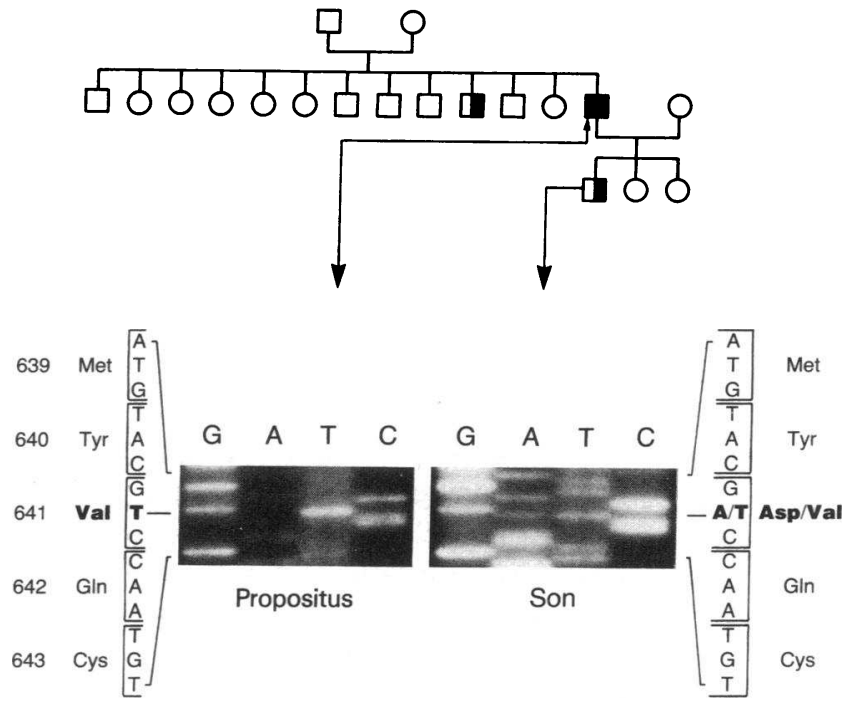

Figure 2. Nucleotide sequence of hGR cDNA from the propositus and his son. The propositus has $\mathrm{T}$ in place of $\mathrm{A}$ at nucleotide 2054, changing the aspartate codon GAC normally present at position 641 to the valine codon, GTC. Both $A$ and $T$ are present at this position in the son's sequence, indicating heterozygosity. 

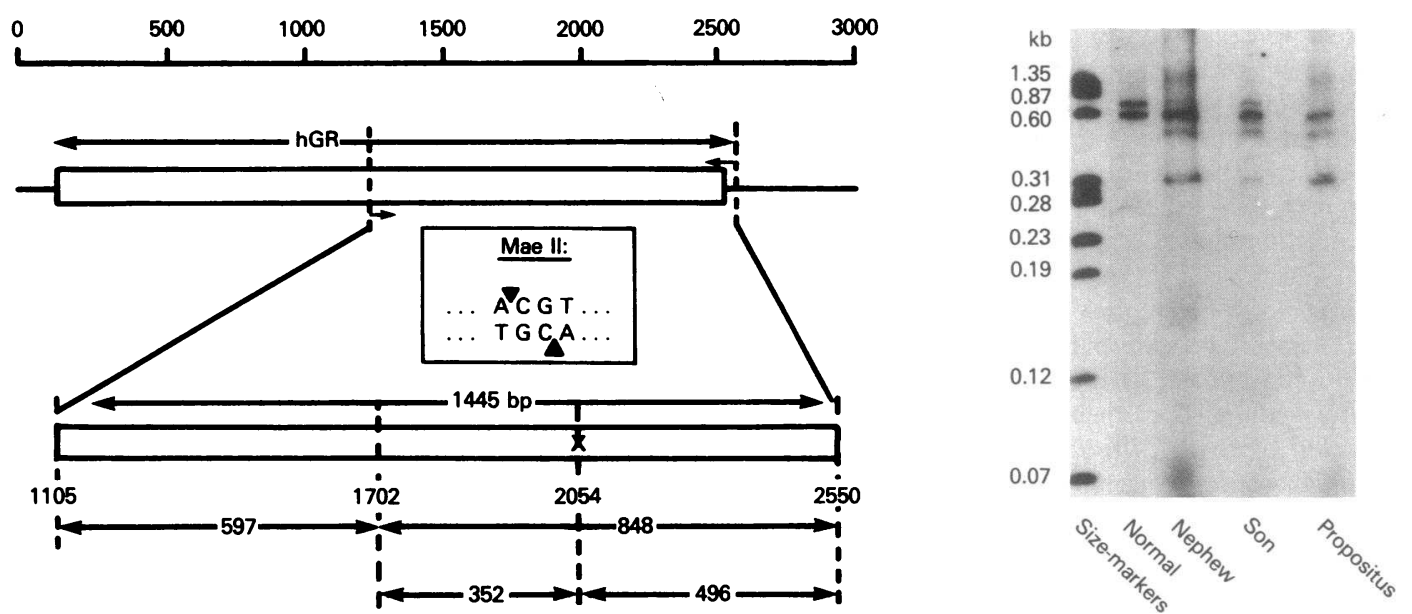

Figure 3. Autoradiography of Mae II-digested hGR cDNA. A segment of hGR CDNA which includes nucleotide 2054 was amplified by PCR from the three patients and from normal hGR cDNA, and digested with the restriction endonuclease Mae II. The diagram shows the normal Mae II restriction site at nucleotide 1702 the predicted extra site caused by the 2054 mutation, and the expected sizes of the digestion products. On the right, the $0.85-\mathrm{kb}$ band, seen in the normal digest, is replaced by 0.35 - and $0.5-\mathrm{kb}$ bands in the propositus digest. In the son and nephew, both the $0.85-\mathrm{kb}$ band and the two smaller bands are present. The results are consistent with the sequencing findings, suggesting that the propositus is homozygous for the extra Mae II site while his relatives are heterozygous.

positus' cDNA produced the $0.6-\mathrm{kb}$ fragment, and fragments of 0.35 and $0.5 \mathrm{~kb}$ instead of the $0.85-\mathrm{kb}$ band, confirming the sequencing results. The smaller bands as well as the $0.85-\mathrm{kb}$ band were present in digests of the two relatives' amplified cDNA consistent, with the sequencing evidence of heterozygosity (Fig. 3).

Allele-specific oligonucleotide hybridization was carried out with an 18 mer mutant nucleotide sequence to detect the mutation. PCR-amplified cDNA from the propositus, normal hGR cDNA, and genomic DNAs from normal subjects were hybridized with the probe. After washing under stringent conditions, the oligonucleotide specifically hybridized to the GR cDNA from the patient. Similar results were obtained when PCR-amplified CDNA of the other two patients were hybridized with the same $18 \mathrm{mer}$, providing a convenient method for the identification of the mutation in subsequent experiments (data not shown).

In order to determine whether the identified base substitution is responsible for glucocorticoid resistance in this kindred, $T$ was inserted in place of $A$ at position 2054 of the normal hGR cDNA in the pRShGR $\alpha$ expression plasmid, creating pRShGR $\alpha$-Val 641 . COS-7 cells were then transfected with either the wild-type or Val 641-mutant plasmid, together with the MMTV-CAT reporter plasmid, in which glucocorticoid response elements (GREs) within the long terminal repeat of the mouse mammary tumor virus are coupled to the CAT gene. The ability of expressed wild type and Val 641-mutant hGR to interact with GRE's and thereby stimulate CAT gene expression was assessed by measuring CAT activity after exposure to increasing doses of dexamethasone. In cells transfected with wild-type plasmid, dexamethasone induced a 20 - to 30-fold increase in CAT activity (Fig. 4). However, there was no stimulation of CAT activity by dexamethasone in cells which had been transfected with the Val 641-mutant plasmid (Fig. 4).

Western blots using monoclonal anti-GR antibody demonstrated similar levels of expression of both wild type and Val 641-mutant GR in transfected COS-7 cells, and confirmed that both species migrated with the expected molecular size (Fig. 5).

Specific high affinity binding $\left[{ }^{3} \mathrm{H}\right]$ dexamethasone was demonstrated in cytosol prepared from Cos-7 cells transfected with pRShGR $\alpha$ (Fig. 5). The binding capacity was $10.4 \mathrm{fmol} / \mathrm{mg}$

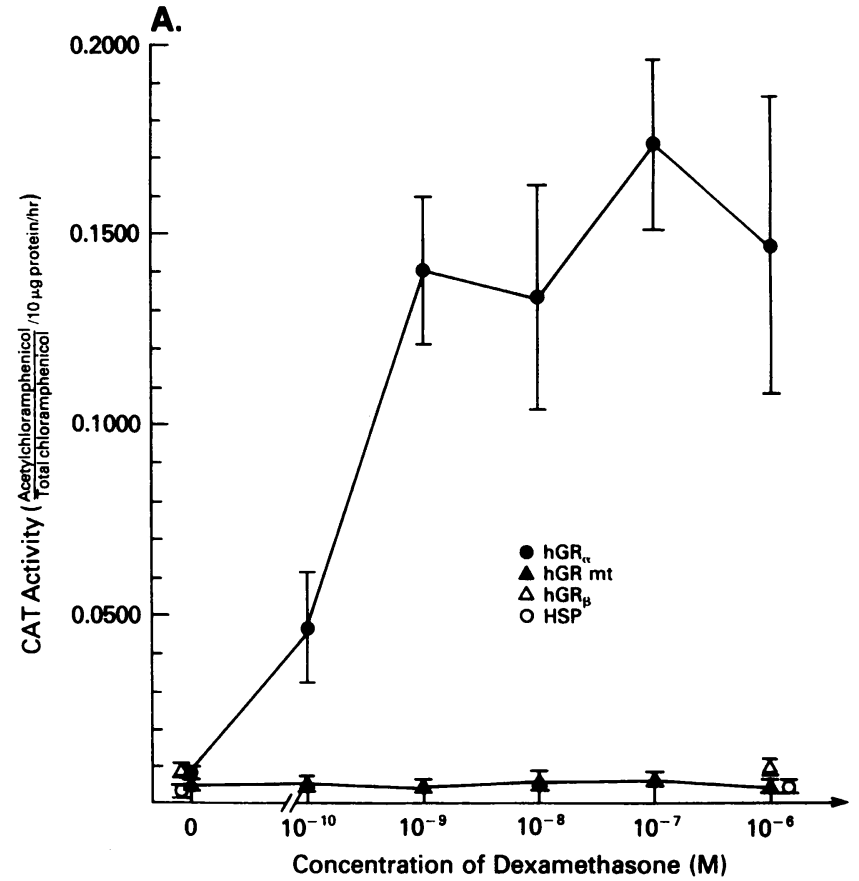

B.

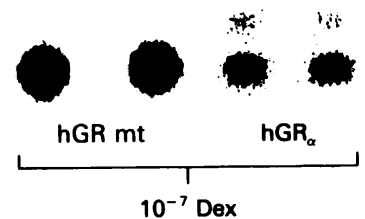

Figure 4. $(A)$ The effect of increasing concentrations of dexamethasone on CAT activity of COS-7 monkey kidney cells cotransfected with either pRShGR $\alpha$ (wild type hGR), pRShGR-Val 641 (mutant hGR), pRShGR $\beta$ (truncated hGR), or phsp90 $\alpha$ (control) and the reporter MMTV-CAT plasmid. ( $B$ ) The autoradiogram shows the conversion of $\left[{ }^{14} \mathrm{C}\right]$ chloramphenicol to its acetylated products. Lowest spots show nonacetylated chloramphenicol, the middle and upper ones represent monoacetylated forms. No conversion was observed with the mutant receptor. 
protein and the dissociation constant $1.3 \mathrm{nM}$. The binding capacity of cytosol from Cos-7 cells transfected with pRShGRVal 641 , on the other hand, was $4.2 \mathrm{fmol} / \mathrm{mg}$ protein, whereas the equilibrum $K_{\mathrm{d}}$ was threefold higher $\left(K_{\mathrm{d}} 3.3 \mathrm{nM}\right)$ than that of the wild type receptor (Fig. 5).

\section{Discussion}

Several lines of evidence indicate that the Val 641 mutation is responsible for impaired ligand binding and glucocorticoid resistance in this kindred. Firstly, the aspartate codon at position 641 lies within the cDNA region that encodes the hormone binding domain of the GR, and is absolutely conserved in the homologous positions of all species studied to date $(2,24,25)$. Interestingly, the human mineralocorticoid receptor also retains an acidic amino acid (glutamate) in this position (26). Secondly, the aspartate residue at position 641 is adjacent to the cysteine residue at position 638 that corresponds to cysteine 656 of the rat GR, which has been shown by covalent labeling with the ligand dexamethasone 21-mesylate to lie within the steroid binding cavity of the receptor, and to be intimately involved in hormone binding $(27,28)$. Modification of thiol groups on this and an adjacent cysteine residue causes a reduction in ligand binding affinity similar to that observed in the FGR kindred, consistent with the concept that amino acids in this region play an important role in high affinity binding. Replacement of the acidic aspartate residue at position 641 with the neutral valine residue, therefore, provides a plausible explanation for impaired ligand binding in this family. Thirdly, segregation of the allele bearing the base substitution is consistent with the conclusion that this mutation causes the glucocorticoid resistant phenotype, with the severely affected propositus being homozygous and his mildly affected relatives being heterozygous. Finally, the fact that no other change was present in the nucleotide sequence of the 2.3-kb coding region of the hGR cDNA of all three patients, strongly suggests that the identified point mutation is not a functionally insignificant polymorphism.
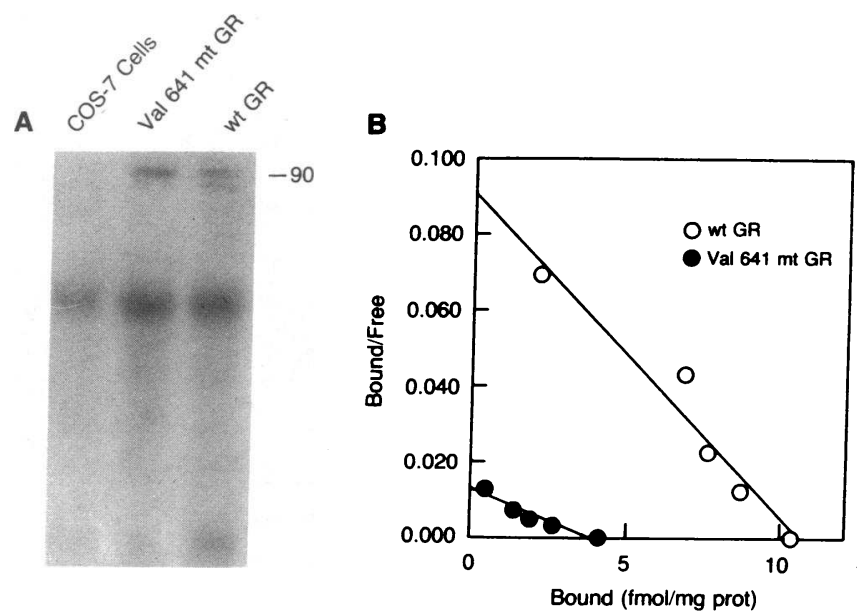

Figure 5. (A) Western blot of protein extracts of Cos-7 cells transfected with wild type-(wt) or Val 641-mutant (mt) GRexpression plasmids. Number 90 indicates the $90-\mathrm{kd}$ band. $(B)$ Scatchard plot of dexamethasone binding to the GR of COS-7 cells transfected with wild type or Val 641-mutant GR expression plasmids. The affinity of the mutant GR was threefold lower than that of the wild type one.
The in vitro expression studies provided definitive confirmation that the Val 641-substituted GR, resulting from replacement of $\mathrm{A}$ by $\mathrm{T}$ at nucleotide position 2054, has reduced ligand binding affinity and impaired ability to activate gene expression through glucocorticoid response elements. This base substitution is, therefore, able to account for the threefold reduction in GR ligand binding affinity and glucocorticoid resistance observed in the propositus of this kindred. The complete lack of CAT induction by dexamethasone in cells transfected with pRShGR-Val 641 mutant plasmid is surprising and suggests that the in vitro COS-7 cotransfection system may differ from the in vivo situation.

The absence of overt evidence of glucocorticoid deficiency in the propositus implies that the increase in plasma corticol concentrations, which occurs in FGR, restores a normal level of glucocorticoid action. This might result from increased GRE occupancy by defective receptor-ligand complexes. Possible mechanisms for reduced transcriptional activity of the Val 641-mutant GR include failure of ligand binding to fully activate the receptor, resulting in reduced GRE binding affinity, impaired receptor dimerization, a process that involves regions of the ligand binding domain (29), and reduced activity of one or more transactivation domains, including those located in the ligand binding domain (29). Further work will be needed to distinguish between these possibilities.

Mild glucocorticoid resistance in heterozygotes may indicate that the GR produced by transcription of the normal allele is unable to maintain homeostasis without elevation of glucocorticoids. An interesting alternative possibility is that mutant receptors interfere with the function of normal receptors, perhaps by preventing appropriate dimerization, or by exerting antagonist effects on GREs, as has been shown for the GRdexamethasone 21-mesylate complex (30). The fact that the GR-dexamethasone mesylate complex has antagonist properties, despite high DNA binding affinity, raises the possibility that the steroid binding domain of the hGR may also be involved in transcriptional regulation, as it has been already shown with mouse GR (31).

Since the initial description and extensive study of this FGR kindred, members of five smaller families with the FGR syndrome have been reported $(8,9,32-34)$. The clinical presentation varied from asymptomatic to hypertension, chronic fatigue, hyperandrogenism in women, and isosexual precocity in a boy. Similarly, the glucocorticoid receptor defects identified varied markedly: decreased ligand binding affinity $(5,9)$, an unstable receptor (32), decreased receptor concentration (33), and a receptor with defective nuclear binding (36) have been reported. Both autosomal recessive and autosomal dominant modes of inheritance have been proposed $(8,10)$. Although detailed DNA studies have not been reported in this syndrome, it seems likely that this state may result from a number of different molecular mechanisms as in other nuclear hormone resistance syndromes (35-39). Because of the potential clinical subtlety of the syndrome and the high prevalence of its varying presentations, mild hypertension, fatigue, and hyperandrogenism, suggest that studies in these patient populations may reveal subgroups with a defined molecular pathophysiology. Direct sequencing of PCR-amplified products provides a powerful tool to identify defects at the hGR gene level. In addition, the use of restriction endonuclease enzymes and/or allele-specific hybridization with synthetic oligonucleotides provides a fast and convenient method for the identification of character- 
ized changes in the hGRcDNA or genomic DNA sequences of other patients.

\section{Acknowledgments}

We thank Dr. Stanley Hollenberg and Dr. Ron Evans for kindly supplying plasmids pRShGR $\alpha$, pRSHGR $\beta$, and pMMTV-CAT, and Drs. A. C. Wikstrom and J. A. Gustafsson for generously donating the antiglucocorticoid receptor monoclonal antibody. Dr. D. M. Hurley was on study leave from the Department of Medicine, University of Western Australia.

\section{References}

1. Evans, R. M. 1988. The steroid and thyroid hormone receptor superfamily. Science (Wash. DC). 240:889-895.

2. Hollenberg, S. M., C. Weinberger, E. S. Ong, G. Cerelli, A. Oro, R. Lebo, E. B. Thompson, M. G. Rosenfield, and R. M. Evans. 1985. Primary structure and expression of a functional human glucocorticoid receptor cDNA. Nature (Lond.). 318:635-641.

3. Francke, U., and B. E. Foellmer. 1989. The glucocorticoid receptor gene is in 5q-q32. Genomics. 4:610-612.

4. Vingerhoeds, A. C. M., J. H. H. Thijssen, and F. Schwartz. 1976. Spontaneous hypercortisolism without Cushing's syndrome. J. Clin. Endocrinol. Metab. 43:1128-1133.

5. Chrousos, G. P., A. Vingerhoeds, D. Brandon, C. Eil, M. Pugeat, M. DeVroede, D. L. Loriaux, and M. B. Lipsett. 1982. Primary cortisol resistance in man. J. Clin. Invest. 69:1261-1269.

6. Linder, M. J., and E. B. Thompson. 1989. Abnormal glucocorticoid receptor gene and mRNA in primary cortisol resistance. J. Steroid Biochem. 32:243249.

7. Brandon, D. D., A. J. Markwick, G. P. Chrousos, and D. L. Loriaux. 1989. Glucocorticoid resistance in humans and nonhuman primates. Cancer Res. 49(Suppl.):2203-2213.

8. Lamberts, S. W. J., D. Poldermans, M. Zweens, and F. H. de Jong. 1986. Familial cortisol resistance differential diagnostic and therapeutic aspects. J. Clin. Endocrinol. Metab. 63:1328-1333.

9. Malchoff, C. D., E. C. Javier, D. M. Malchoff, T. Martin, A. Rogol, D. Brandon, D. L. Loriaux, and G. E. Reardon. 1990. Primary cortisol resistance presenting as isosexual precocity. J. Clin. Endocrinol. Metab. 70:503-507.

10. Chrousos, G. P., A. C. M. Vingerhoeds, D. L. Loriaux, and M. B. Lipsett. 1983. Primary cortisol resistance: a family study. J. Clin. Endocrinol. Metab. 56:1243-1245

11. Lipsett, M. B., G. P. Chrousos, M. Tomita, D. D. Brandon, and D. L. Loriaux. 1985. The defective glucocorticoid receptor in man and nonhuman primates. Rec. Prog. Horm. Res. 41:199-247.

12. Tomita, M., D. D. Brandon, G. P. Chrousos, A. C. M. Vingerhoeds, C. M Foster, D. Fowler, D. L. Loriaux, and M. B. Lipsett. 1986. Glucocorticoid receptors in Epstein-Barr virus-transformed lymphocytes from patients with glucocorticoid resistance and a glucocorticoid-resistant New World primate species. $J$. Clin. Endocrinol. Metab. 62:1145-1154.

13. Saiki, R. K., D. H. Gelfand, S. Stoffel, S. J. Scharf, R. Higuchi, G. T. Horn K. B. Mullis, and H. A. Erlich. 1988. Primer-directed enzymatic amplification of DNA with a thermostable DNA polymerase. Science (Wash. DC). 239:487-491.

14. Marcus-Samuels, B., and S. I. Taylor. 1988. Insulin Receptors in EpsteinBarr Virus-transformed lymphocytes. Insulin Receptors, Part A: Methods for the Study of Structure and Function. Alan R. Liss, Inc., New York. 249-254.

15. Chomcynski, P., and N. Sacchi. 1987. Single-step method of RNA isolation by acid guanidinium thiocynate-phenol-chloroform extraction. Anal. Biochem. 162:156-159.

16. Kadowaki, T., H. Kadowaki, and S. I. Taylor. 1990. A nonsense mutation causing decreased levels of insulin receptor mRNA: detection by a simplified technique for direct sequencing of genomic DNA amplified by the polymerase chain reaction. Proc. Natl. Acad. Sci. USA. 87:658-662.

17. Sanger, F., S. Nicklen, and A. R. Coulson. 1977. DNA sequencing with chain terminating inhibitors. Proc. Natl. Acad. Sci. USA. 74:5463-5467.

18. Southern, E. M. 1975. Detection of specific sequences among DNA fragments separated by gel electrophoresis. J. Mol. Biol. 98:503-515.
19. Accili, D., C. Frapier, L. Mosthaf, C. McKeon, S. C. Elbein, M. A. Permutt, E. Ramos, E. Lander, A. Ullrich, and S. I. Taylor. 1989. A mutation in the insulin receptor gene that impairs transport of the receptor to the plasma membrane and causes insulin-resistant diabetes. EMBO (Eur. Mol. Biol. Organ.) J. 8:2509-2517.

20. Ho, S. N., H. D. Hunt, R. M. Horton, J. K. Pullen, and L. R. Pease. 1989. Site-directed mutagenesis by overlap extension using the polymerase chain reaction. Gene. 77:51-5.

21. Giguere, V., S. M. Hollenberg, M. G. Rosenfeld, and R. M. Evans. 1986. Functional domains of the human glucocorticoid receptor. Cell. 46:645-652.

22. Felgner, P. L., T. R. Gadek, M. Holm, R. Roman, H. Chan, M. Wenz, J. Northrop, G. Ringold, and M. Danielsen. 1987. Lipofectin: a highly efficient, lipid-mediated DNA-transfection procedure. Proc. Natl. Acad. Sci. USA. 84:7413-7417.

23. Gorman, C. M., L. F. Moffat, and B. H. Howard. 1982. Recombinant genomes which express chloramphenicol acetyltransferase in mammalian cells. Mol. Cell. Biol. 2:1044-1051.

24. Miesfeld, R, S. Rusconi, P. J. Godowski, B. A. Maler, S. Okrets, A. C Wikstrom, J. A. Gustaffsson, and K. R. Yananoto. 1986. Genetic complementation of a glucocorticoid receptor cDNA. Cell. 46:389-399.

25. Danielsen, M., J. P. Northrop, and G. M. Ringold. 1986. The mouse glucocorticoid receptor: mapping of functional domains by cloning, sequencing and expression of wild type and mutant receptor proteins. EMBO (Eur. Mol. Biol. Organ.) J. 5:2513-2522.

26. Arriza, J. L., C. Weinberger, G. Cerelli, T. M. Glaser, B. L. Handelin, D. E. Housman, and R. M. Evans. 1987. Cloning of human mineralococorticoid receptor complementary DNA: structural and functional kinship with the glucocorticoid receptor. Science (Wash. DC). 237:268-275.

27. Simons, S. S., J. G. Pumphrey, S. Rudikoff, and H. J. Eisen. 1987. Identifcation of cysteine 656 as the amino acid of hepatoma tissue culture cell glucocorticoid receptors that is covalently labeled by dexamethasone 21-Mesylate. J. Biol. Chem. 262:9676-9680.

28. Miller, N. R., and S. S. Simons, Jr. 1988. Steroid binding to hepatoma tissue culture cell Glucocorticoid receptors involves at least two sulfhydryl groups. J. Biol. Chem. 263:15217-15225.

29. Beato, M. 1989. Gene regulation by steroid hormones. Cell. 56:335-344.

30. Simons, S. S. Jr., P. A. Miller, G. Wasner, N. R. Miller, and L. Mercier. 1988. Inverse correlation between dexamethasone 21-mesylate agonist activity and sensitivity to dexamethasone for induction of tyrosine aminotransferase in rat hepatoma cells. J. Steroid Biochem. 31:1-7.

31. Danielsen, M., L. Hinck, and G. M. Ringold. 1989. Mutational analysis of the mouse glucocorticoid receptor. Cancer Res. 49(Suppl.):2286-2291.

32. Bronnergard, M., S. Werner, and J.-A. Gustafsson. 1986. Primary cortisol resistance associated with a thermolabile glucocorticoid receptor in a patient with fatigue as the only symptom. J. Clin. Invest. 78:1270-1278.

33. Iida, S., M. Gomi, K. Moriwaki, Y. Itoh, K. Hirobe, Y. Matsuzawa, S. Katagiri, T. Yonezawa, and S. Tarui. 1985. Primary cortisol resistance accompanied by a reduction in glucocorticoid receptors in two members of the same family. J. Clin. Endocrinol. Metab. 60:967-971.

34. Nawata, H., K. Sekiya, K. Higuchi, K. Kato, and H. Ibayashi. 1987. Decreased deoxyribonucleic acid binding of glucocorticoid-receptor complex in cultured skin fibroblasts from a patient with the glucocorticoid resistance syndrome. J. Clin. Endocrinol. Metab. 65:219-226.

35. Griffin, J. E., and J. D. Wilson. 1980. The syndromes of androgen resistance. N. Engl. J. Med. 302:198-209.

36. Marcelli, M., W. D. Tilley, C. M. Wilson, J. D. Wilson, J. E. Griffin, and M. J. McPhaul. 1990. A single nucleotide substitution introduces a premature termination codon into the androgen receptor gene of a patient with receptornegative androgen resistance. J. Clin. Invest. 85:1522-1528.

37. Hughes, M. R., P. J. Maloy, D. G. Kieback, R. A. Kesterson, J. W. Pike, D. Feldman, and B. W. O'Malley. 1988. Point mutations in the human vitamin D receptor gene associated with hypercalcemic rickets. Science (Wash. DC). 242:1702-1705.

38. Usala, S. J., G. E. Tennyson, A. E. Bale, R. W. Lash, N. Gesundheit, F. E. Wondisford, D. Accili, P. Hauser, and B. D. Weintraub. 1990. A base mutation of the C-erbA $\beta$ thyroid hormone receptor in a kindred with generalized thyroid hormone resistance. J. Clin. Invest. 85:93-100.

39. Sakurai, A., K. Takeda, K. Ain, P. Ceccarelli, A. Nakai, S. Seino, G. I. Bell, S. Refetoff, and L. J. deGroot. 1989. Generalized resistance to thyroid hormone associated with a mutation in the ligand-binding domain of the human thyroid hormone receptor $\beta$. Proc. Natl. Acad. Sci. USA. 86:8977-8981. 